\section{Antagonisme Bakteri terhadap Kapang Patogen pada Lahan Pertanian Tomat di Kabupaten Malang}

Mustaqim', Dasriani'2, Muhammad Fahrurrizal A. ${ }^{3}$, Hanifah Rahmawati ${ }^{4}$, Putri Dhamira5

Universitas Negeri Malang

Email: Mustaqim.abdimars@gmail.com¹

Abstract. Efforts in overcoming the problem of pathogenic mold attack can be done with the use of bacteria. This study aims to isolate the bacteria potentially controlling pathogenic molds in tomato plants (Solanum lycoperscium), as well as to identify potential bacteria controlling pathogenic fungi in tomato plants (Solanum lycoperscium) in Malang Regency. This research is an experimental laboratory study with a randomized block design (RCBD). This study used a Randomized Block Design because the experimental unit used was heterogeneous originating from 3 different locations. Of the 20 types of bacterial isolates, there are 6 bacteria that have the potential to inhibit the growth of Fusarium solani fungi that cause wilt disease in tomato plants, namely labeled bacteria EK, IK, BK, KK, CK and OK. There are six colonies that can act as antagonists of the fungus F. solani. It can be estimated that the six bacteria have the power to remodel and use carbon compounds. The carbon compounds such as arabinosa, xylosa, dextrose, cellobinosa, maltose, mannitol, sorbitol, and the use of citrate.

Keywords: Bacteria antogonism, mold pathogens, tomato farming

\section{INDONESIAN JOURNAL OF FUNDAMENTAL SCIENCES \\ (IJFS)}

\section{E-ISSN: 2621-6728 \\ P-ISSN: 2621-671X}

Submitted: January, $4^{\text {th }} 2020$

Accepted: March, $2^{\text {nd }} 2020$

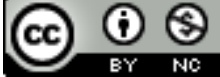

This work is licensed under a Creative Commons Attribution-NonCommercial 4.0 International License 


\section{PENDAHULUAN}

Tomat (Solanum lycoperscium) merupakan komoditas utama sebagai bahan makanan pokok sebagian besar masyarakat Indonesia. Salah satu usaha intensifikasi yang telah dilakukan adalah pemberian pestisida yang cukup terhadap tanaman tomat yang akan mencegah terjadinya mikroorganisme pengganggu tanaman. Masing-masing jenis mikroorganisme tersebut mempunyai karakteristik sendirisendiri baik dalam bentuk, cara hidup (cara menyerang) pada tanaman sebagai patogen tanaman (Agrios, 2005). Namun, usaha intesifikasi ini terkendala dengan kelangkaan dan mahalnya harga pestisida yang berdampak pada kurangnya pemberian pestisida sehingga terjadi penurunan produktivitas tomat akibat mikroorganisme pengganggu. Salah satu mikroorganisme yang sering ditemui menyerang tomat di Indonesia adalah kapang.

Usaha untuk mengatasi permasalahan kapang selain dengan penggunaan pestidisida adalah menggunakan bakteri yang berperan secara antagonisme terhadap perkembangan hama. Penggunaan bakteri memiliki peran penting untuk meningkatkan kesuburan tanah, promosi pertumbuhan tanaman, dan pengendalian kapang patogen untuk pengembangan pertanian berkelanjutan ramah lingkungan (Gupta dan Sushama, 2015).

Beberapa penelitian memperlihatkan bahwa penggunaan bakteri mampu mengendalikan patogen tanaman dengan mekanisme antibiosis dan persaingan nutrisi sehingga mengurangi pemakaian petisida antibakteri secara berlebihan (Sutariati, 2006). Khaeruni dkk. (2013) menunjukkan bahwa penggunaan bakteri isolat P11a dan PKLK5 yang diisolasi mampu menginduksi ketahanan tanaman padi IR64 terhadap penyakit HDB pada skala rumah kasa.

Berdasarkan informasi tersebut, penting dilakukan isolasi dan identifikasi bakteri akar tomat di persawahan Kabupaten Pasuruan. Isolasi dan identifikasi bakteri ini penting dilakukan untuk menemukan spesies akteri yang spesifik untuk tanaman padi lokal yang disertai kemampuan mengendalikan penyakit yang disebabkan oleh kapang. Selanjutnya spesies-spesies bakteri tersebut diharapkan akan berguna dalam usaha membantu meningkatkan ketahanan tumbuhan padi terhadap penyakit yang pada akhirnya akan mengurangi biaya yang dikeluarkan petani untuk pestisida bakteri berupa bahan kimia dan mengurangi residu pada lingkungan.

Penelitian ini bertujuan untuk Untuk mengisolasi bakteri berpotensi pengendali kapang patogen pada tanaman tomat (Solanum lycoperscium), mengetahui kemampuan uji antogonisme antara bakteri yang diisolasi dengan kapang pathogen serta untuk mengidentifikasi bakteri berpotensi pengendali kapang patogen pada tanaman tomat (Solanum lycoperscium) di Kabupaten Malang. Secara keseluruhan, manfaat dari penelitian ini adalah Sebagai bahan referensi terkait pengembangan pestisida antikapang organik untuk mengendalikan penyakit pada tanaman tomat

\section{METODE PENELITIAN}

Penelitian ini merupakan penelitian eksperimental laboratorium dengan rancangan acak kelompok (RAK). Penelitian ini menggunakan Rancangan Acak Kelompok karena satuan percobaan yang digunakan bersifat heterogen yang berasal 
dari 3 lokasi yang berbeda sehingga terdapat faktor lain yang dapat mempengaruhi respon di luar faktor yang sedang diteliti.

Kegiatan penelitian ini dimulai dari observasi lapangan yang dilanjutkan pengambilan sampel tanah dari tiga kecamatan di kabupaten Malang. Selanjutnya sampel tanah tersebut diuji di dalam laboratorium Mikrobiologi, fakultas matematika dan ilmu pengetahuan alam, Universitas Negeri Malang. Penelitian ini akan dilaksanakan mulai bulan oktober hinggan November 2017.

Pengambilan sampel dilakukan dengan mengambil tanah dekat dengan akar tumbuhan yang terjangkit dengan kedalaman 10-15 cm dibawah permukaan tanah. Pengambilan sampel ini dilakukan di tiga kecamatan di wilayah Kabupaten Malang dengan masing-masing kecamatan akan diambil tiga titik pengambilan sampel. Selain mengambil tanah sebagai sampel, juga dilakukan beberapa pengukuruan terhadap tanah, seperti suhu, kelembaban, dan $\mathrm{pH}$ tanah, sebagai penguat data dalam analisis. Isolasi bakteri dan kapang diawali dengan pengeceran tanah dengan menggunakan akuades hingga pengenceran $10^{-9}$. Kemudian hasil pengenceran tanam di medium lempeng PDA/PCA dan diinkubasi selama 24-36 jam. Dilakukan isolasi bakteri/kapang dengan menginokulasikan tiap koloni yang berbeda ke dalam medium miring.

Identifikasi pada bakteri dengan pengamatan mikroskop dan dilakukan serangkaian pengujian, seperti pewarnaan gram, agar diperoleh hasil amatan hingga tingkat spesies dan mengetahui karakteristik dari bakteri. Untuk kapang, digunakan teknik micro slide agar diperoleh amatan secara jelas. Uji antagonisme bakteri dan kapang patogen ini dilakukan dengan penginokulasian bakteri (hasil pengambilan dengan bor gabus) kedalam biakan kapang patogen pada medium lempeng. Diinkubasikan selama 24-36 jam, kemudian diamati zona hambat yang terbentu. Data hasil uji antagonisme ini yang diperoleh kemudian dianalisis dengan analisis varian (ANAVA) tiga jalur dengan menggunakan uji $\mathrm{F}$ dan uji beda berdasarkan Uji Beda Nyata Terkecil dengan taraf 0,05.

\section{HASIL DAN PEMBAHASAN}

\section{Isolasi Bakteri Pada Tanaman Tomat}

Pengambilan isolat alami bakteri penghambat pertumbuhan kapang yang menyebabkan layu pada tanaman tomat dilakukan di tiga kecamatan di Kabupaten Malang yaitu Tumpang, Karanganyar dan Puncokusumo. Ketiga daerah ini memiliki karakteristik lahan perkebunan tomat yang berbeda. Suhu tanah pada lahan perkebunan tomat di Tumpang yaitu $26^{\circ} \mathrm{C}$ sedangkan $\mathrm{pH}$ nya yaitu 6,5 . Suhu tanah pada lahan perkebunan tomat di Karanganyar yaitu $28{ }^{\circ} \mathrm{C}$ dengan pH yaitu 7 . Sedangkan suhu tanah pada lahan pertanian Puncokusumo yaitu $27^{\circ} \mathrm{C}$ dengan $\mathrm{pH}$ yaitu 6.

Bakteri yang diduga memiliki kemampuan untuk menghambat pertumbuhan kapang penyebab layu pada tanaman tomat (Fusarium solani) berhasil diisolasi yang diambil dari tanah dekat akar tanaman tomat yang terserang penyakit layu yang ditunjukkan pada gambar berikut. 

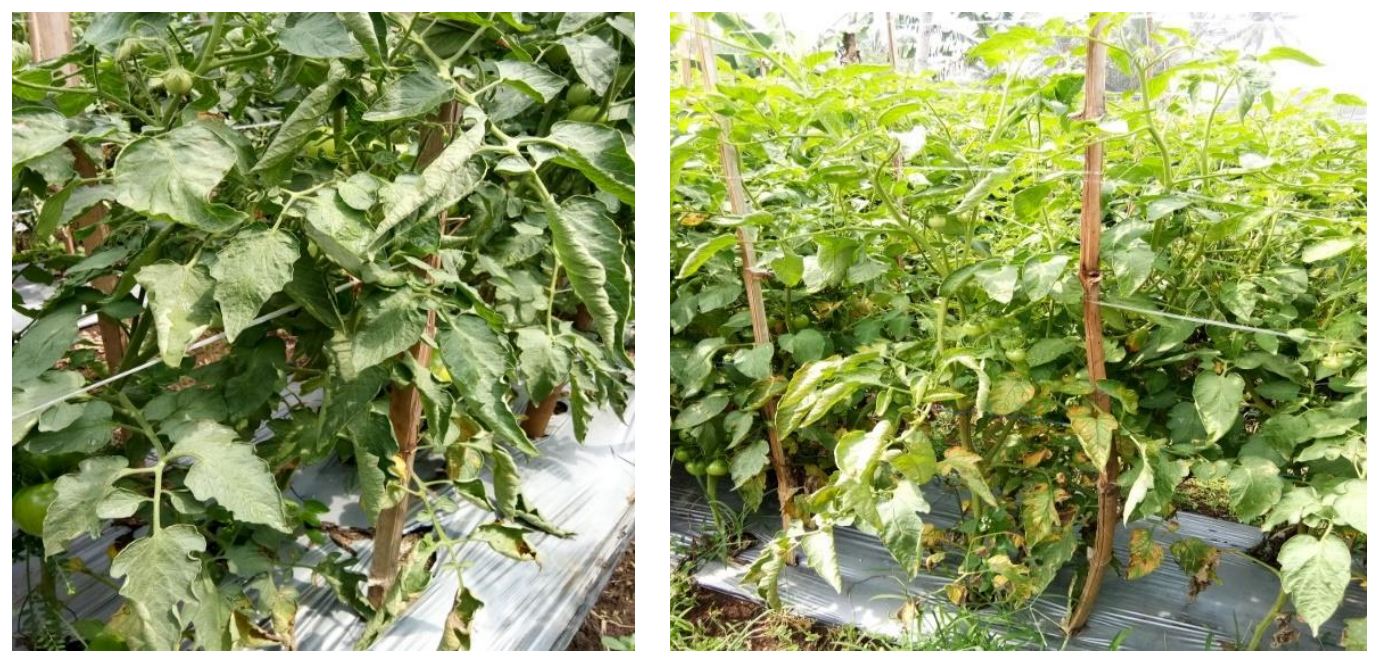

Gambar 1. Daun laun pada tanaman tomat yang disebabkan oleh kapang patogen Fusarium solani

Ada 20 isolat bakteri yang berhasil diisolasi pada lokasi Tumpang dengan label yaitu RT, PT, TT, ST, dan QT. Pada lokasi Karanganyar terdapat isolate dengan label CK, GK, AK, NK, JK, MK, OK, DK, KK, BK, TK, EK, dan HK. Sementara di lokasi Puncokusumo terdapat isolat bakteri dengan label UP. Dari 20 jenis isolate bakteri tersebut, ada 6 bakteri yang memiliki potensi menghambat pertumbuhan kapang Fusarium solani penyebab penyakit layu pada tanaman tomat.

\section{Uji Antagonisme}

Uji antagonisme dilakukan dengan menggunakan medium uji Natrium Agar (NA) yang telah diolesi dengan bakteri yang diduga memilki kemampuan menghambat pertumbuhan kapang patogen pada tanaman tomat. Mekanisme penghambatan bakteri terhadap kapang patogen dapat diamatai dari terbentuknya zona bening pada medium uji. Berikut adalah hasil pengamatan dari uji antagonisme.

Tabel 1. Hasil pengamatan uji antagonism bakteri terhadap kapang patogen (Fusarium solani) penyebab penyakit layu pada tanaman tomat.

\begin{tabular}{cccc}
\hline No & Isolat & Ulangan & Pertumbuhan Kapang \\
\hline $\mathbf{1}$ & RT & 1 & +++ \\
\hline $\mathbf{2}$ & HK & 1 & +++ \\
\hline 3 & EK & 1 & - \\
\hline 4 & IK & 1 & -- \\
\cline { 3 - 4 } & & 2 & -- \\
\hline 5 & BK & 1 & -- \\
\cline { 3 - 4 } & & 2 & -- \\
\hline 6 & LK & 1 & + \\
\cline { 3 - 4 } & & 2 & ++ \\
\hline 7 & KK & 1 & -- \\
\cline { 3 - 4 } & & 2 & + \\
\hline 8 & PT & 1 & ++ \\
\cline { 3 - 4 } & & 2 & \\
\hline
\end{tabular}




\begin{tabular}{|c|c|c|c|}
\hline & & 3 & + \\
\hline \multirow[t]{2}{*}{9} & TT & 1 & + \\
\hline & & 2 & + \\
\hline \multirow[t]{2}{*}{10} & DK & 1 & + \\
\hline & & 2 & + \\
\hline \multirow[t]{2}{*}{11} & CK & 1 & -- \\
\hline & & 2 & - \\
\hline 12 & GK & 1 & + \\
\hline \multirow[t]{2}{*}{13} & ST & 1 & +++ \\
\hline & & 2 & ++++ \\
\hline 14 & $\mathrm{QT}$ & 1 & + \\
\hline \multirow[t]{2}{*}{15} & AK & 1 & + \\
\hline & & 2 & + \\
\hline \multirow[t]{2}{*}{16} & NK & 1 & + \\
\hline & & 2 & + \\
\hline \multirow[t]{4}{*}{17} & JK & 1 & ++ \\
\hline & & 2 & ++ \\
\hline & & 3 & + \\
\hline & & 4 & + \\
\hline 18 & MK & 1 & ++ \\
\hline \multirow[t]{2}{*}{19} & UP & 1 & +++ \\
\hline & & 2 & + \\
\hline \multirow[t]{2}{*}{20} & OK & 1 & - \\
\hline & & 2 & - \\
\hline
\end{tabular}

Keterangan:

$+\quad$ : tumbuh hingga ke potongan pinggir PDA

$+\quad$ : $\quad$ : tumbuh hingga di NA di sekeliling PDA

+++ $\quad$ : tumbuh lebih lebar

- $\quad$ : tidak tumbuh hingga ke potongan pinggir PDA

-- $\quad$ : $\quad$ : koloni mengering dan luasan berkurang

--- : : koloni mengering dan mulai banyak berkurang bila dibandingkan dengan (-

-)

Dari 20 jenis isolat bakteri tersebut, ada 6 bakteri yang memiliki potensi menghambat pertumbuhan kapang Fusarium solani penyebab penyakit layu pada tanaman tomat yaitu bakteri belabel EK, IK, BK, KK, CK dan OK. Kemudian 6 isolat bakteri di atas kemudian diuji kembali untuk mengetahui manakah isolat bakteri yang lebih menekan pertumbuhan kapang patogen.

Tabel 2. Bakteri yang memiliki kemampuan menghambat Fusarium solani

\begin{tabular}{cccc}
\hline No & Kode Bakteri & Ulangan & Pertumbuhan Kapang \\
\hline 1 & EK & 1 & - \\
2 & IK & 1 & - \\
& & 2 & -- \\
3 & BK & 1 & - \\
& & 2 & -- \\
4 & KK & 1 & -- \\
& & 2 & --
\end{tabular}


Penekanan pertumbuhan kapang patogen $F$. solani oleh bakteri antagonis yang ditemukan di kawasan karanganyar memiliki daya yang berbeda. Daya antagonis yang terlihat paling besar dimiliki oleh bakteri KK. Bakteri ini mampu menekan pertumbuhan kapang. Terlihat dengan tidak adanya kapang yang tumbuh di tepian potongan medium PDA, bahkan terlihat bahwa potongan medium tersebut sudah mulai sedikit bagian yang ditumbuhi oleh koloni $F$. solani. Keberagaman daya ini disebabkan oleh faktor, salah satunya adalah kemampuan metabolisme dari bakteri tersebut.
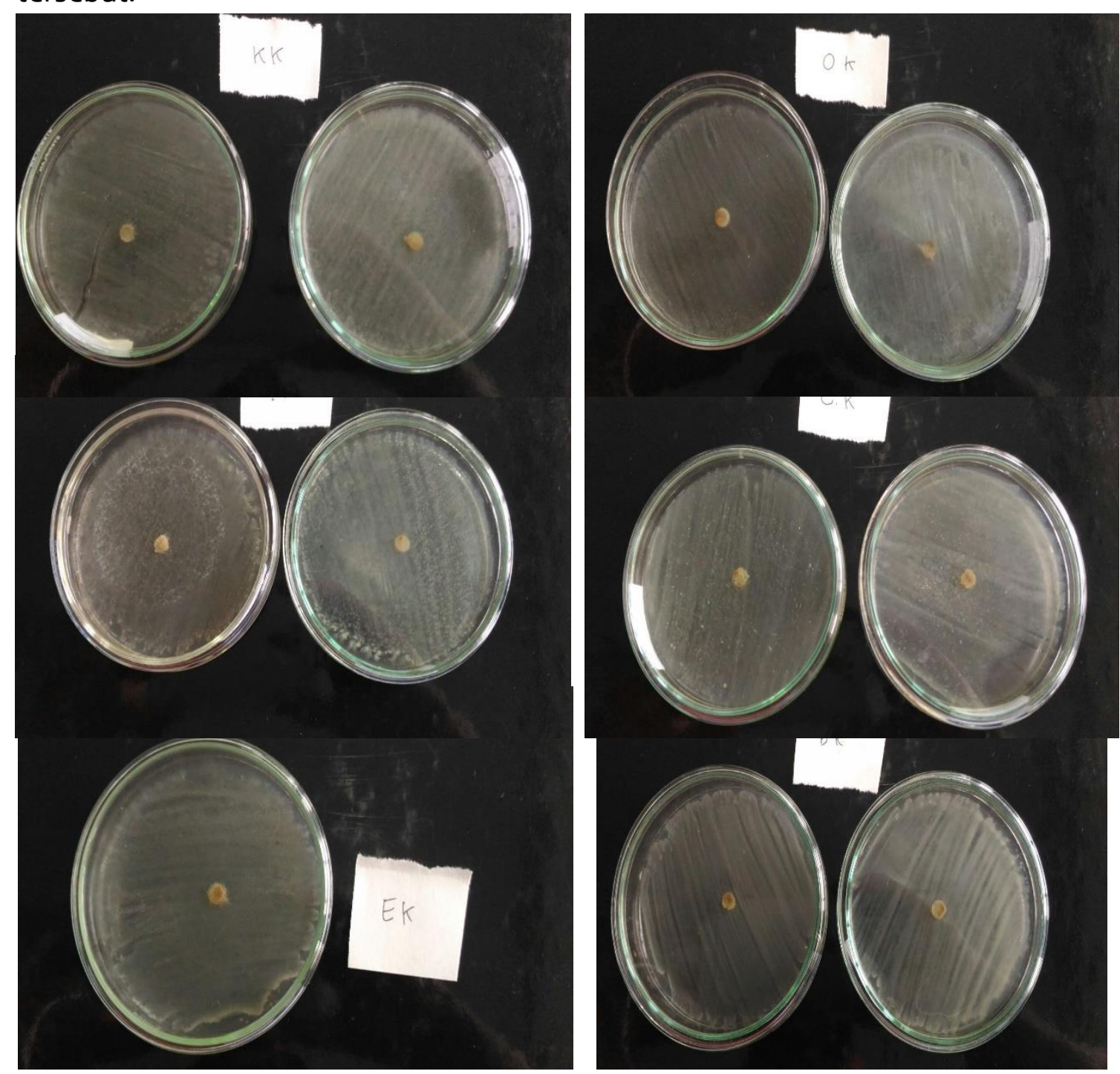

Gambar 2. Hasil inokulasi kapang dengan bakteri

Terlihat dari kemampuan dalam menekan pertumbuhan kapang, maka dapat diperkirakan bahwa keenam bakteri tersebut memiliki daya dalam merombak dan menggunakan senyawa karbon. Senyawa-senyawa karbon tersebut seperti 
arabinosa, xylosa, dekstrosa, selobinosa, maltosa, manitol, sorbitol, dan penggunaan sitrat (Saputra, 2015). Selain itu dimungkinkan pula bekateri-bakteri tersebut memiliki kemampuan untuk menghasilkan enzim hidrolitik dan mendegradasi zat organik disekitarnya, termasuk kapang patogen. Perlu dilakukan pengujian lanjut secara fisiologis, biokimia, dan identifikasi lebih lanjut untuk mengetahui daya antagonisme keenam bakteri tersebut pada kapang patogen $F$. solani.

\section{KESIMPULAN}

Terdapat enam koloni yang dapat bertindak sebagai antagonis dari kapang $F$. solani. Dapat diperkirakan bahwa keenam bakteri tersebut memiliki daya dalam merombak dan menggunakan senyawa karbon. Senyawa-senyawa karbon tersebut seperti arabinosa, xylosa, dekstrosa, selobinosa, maltosa, manitol, sorbitol, dan penggunaan sitrat. Selain itu dimungkinkan pula bekateri-bakteri tersebut memiliki kemampuan untuk menghasilkan enzim hidrolitik dan mendegradasi zat organik disekitarnya, termasuk kapang pathogen

\section{DAFTAR PUSTAKA}

Agrios, G., N. 2005. Plant Patology. Fifth Edition. Elsevier Academic Press. New York.

Gupta, Amit dan Sushama R. Chaphakar. 2015. Immunosuppressive Activity of Crude Saponins From The Leaves of Calotropis gigantea, Calamus roteng, and Artocarpus integrifolia. International Research Journal of Pharmaceutical and Applied Sciences (IRJPAS) Vol. 6 No. 3 Hal: 526-531.

Khaeruni, A, Sutariati, G.A.K., dan Wahyuni, S., 2010. Karakterisasi dan Uji Aktivitas Bakteri Rizosfer Lahan Ultisol sebagai Pamacu Pertumbuhan Tanaman dan Agens Hayati cendawan patogen tular tanah secara in-vitro. J. HPT Tropika 10 (2): 123-130.

Saputra, R., dkk. 2015. Uji Aktvitas Antagonostik beberapa Isolat Bacillus spp. Terhadap penyakit layu bakteri (Ralstonia solanacearum) pada varietas tomat dan identifikasinya, Pros SEM NAS MASY BIODIV INDON, 1(5), 1116-1122.

Sutariati, G.A.K., Widodo., Sudarsono, dan Satriyas I. 2006. Pengaruh Perlakuan Rizobakteri Pemacu Pertumbuhan Tanaman terhadap Viabilitas Benih serta Pertumbuhan Bibit Tanaman Cabai. J. Agronomi Indonesia. 